IRA-International Journal of Education \& Multidisciplinary Studies ISSN 2455-2526; Vol.06, Issue 01 (2017) Pg. no. 113-133

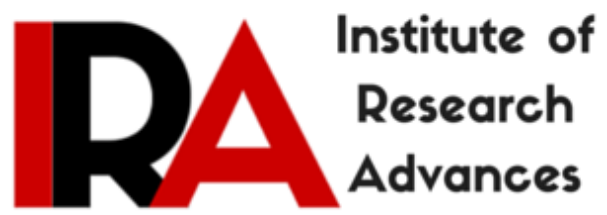

\title{
Impact of MGNREGA on Tribal Migration in Sarenga Development Block
}

\author{
Monaj Kumar Pahari \\ Faculty Member \\ B R Ambedkar Institute of Panchayats \& Rural Development (Formerly SIPRD), \\ West Bengal, India.
}

Type of Review: Peer Reviewed.

DOI: http://dx.doi.org/10.21013/jems.v6.n1.p9

\section{How to cite this paper:}

Pahari, M. (2017). Impact of MGNREGA on Tribal Migration in Sarenga Development Block. IRA International Journal of Education and Multidisciplinary Studies (ISSN 2455-2526), 6(1), 113-133. doi:http://dx.doi.org/10.21013/jems.v6.n1.p9

(C) Institute of Research Advances

\section{(cc) EY-NC}

This work is licensed under a Creative Commons Attribution-Non Commercial 4.0 International License subject to proper citation to the publication source of the work.

Disclaimer: The scholarly papers as reviewed and published by the Institute of Research Advances (IRA) are the views and opinions of their respective authors and are not the views or opinions of the IRA. The IRA disclaims of any harm or loss caused due to the published content to any party. 


\begin{abstract}
Mahatma Gandhi National Rural Employment Guarantee Programme is one of the most important and largest public programme in India. The main objective of this programme is to provide 100 days of assured employment to rural household and to create sustainable asset. In this paper we have studied the secondary objective of MGNREGA that is to reduce migration and creation of sustainable asset in light of tribal perspective. In this paper we work in migration data for July 2007 to June 2008 NSSO \& Census of India, 2011 data. By our analysis we find that Migration is a complex process, it is not always done due to poverty and desperate situation, but complex factors (facilities, education). People especially tribals are migrating due to lack of adequate agricultural land, inadequate agricultural production, less irrigation facilities, and acute water scarcity and stringent enforcement of Forest Laws before implantation of Forest Act. At the macro level analysis, correlation between migration and MGNREGA is very weak. From the literature as well as supported by the micro-assessment, MGNREGA is helping poor and weaker section of the community by providing employment at critical period of a year (seasonal migration). In principal, MGNREGA can help to reduce temporary migration but is ineffective in long period, when several factors would change together.
\end{abstract}

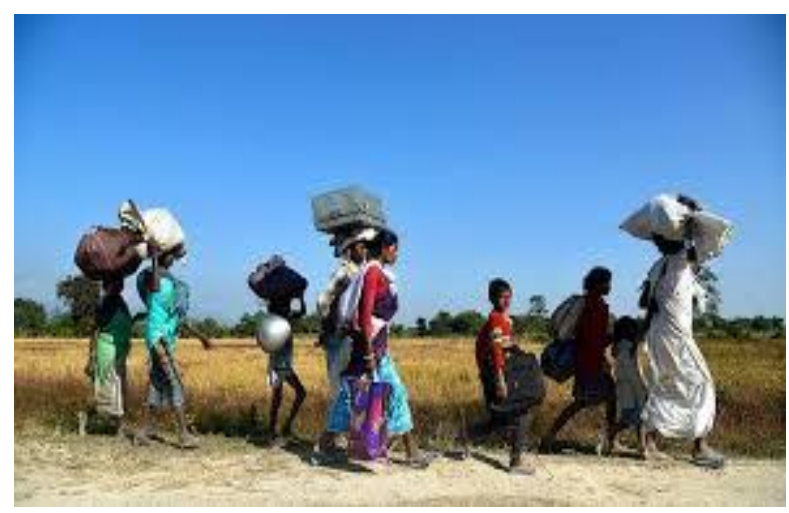

Image No: I A Tribal Family is Going to "Pub" for Job.

\title{
1. Introduction:
}

It is quite widely known that most of India's rural inhabitants are poor and live in poverty, which has been supported by several studies. This is a fact that even after 68 years of independence and 65 years of implementation of several policies on development in tribal areas and various new legislations and schemes adopted for better human development in tribal areas by various national and state governments from time to time, the living standard of tribals of West Bengal in particular has improved very little compared to the other states of the country. However, Indian economy continues to be predominantly rural in character thus there were growing incidents of poverty, deprivation, discrimination, hunger, widespread unemployment, under-employment, social inequalities, illiteracy, ill health, high rate of IMR and MMR, distress among the farmer causing suicide, droughts, inadequate employment in the tribal areas leading to huge migration among the tribals either to the cities or neighboring states. Planners, of late, have realized that the strategy of economic growth through industrialization may not bring the benefits of development to the poorest of rural poor and that they may continue to suffer from poverty, inequality, and unemployment for years to come. It is therefore, thought necessary to develop alternative approaches and launch special programmes which will address these problems and to enhance livelihood security to rural unemployed while producing durable assets, empowering women, reducing distress migration and promoting social equity. In this context, the Government of India (GOI) enacted the National Rural Employment Guarantee Act (NREGA) in 2005. Being the largest public work programme 
a lot has been expected from MGNREGA since its inception and thus it has always been in limelight. MGREGA is different from earlier employment programmes launched by Government of India as on one hand it is a demand driven scheme while on the other hand it treats employment as right of rural household. This scheme provides income directly to unskilled workers in rural areas. A lot of case studies have been reported of NREGA workers gigging ditches and refilling them at work site, of workers not being paid wages and of inflated muster rolls with not existent workers. Despite these challenges it can be clearly seen from last NREGA report that number of households with NREGA are increasing constantly and also are the number of days providing employment. One of the major achievements of this scheme is increasing participation of women. By proving equal wage rate to men and women this scheme has empowered economically and socially. NREGA funding has increased drastically by total budget outlay of 11300 in 2006 to 4568332.63 lakh in 2015-16 in financial year as can be seen in figure-I.( source: www.nrega.nic.in)

\section{MGNREGA: Financial Achievements at a glance}

\begin{tabular}{|c|c|c|c|c|c|c|c|c|c|}
\hline & FY 06-07 & FY 07-08 & FY 08-09 & FY 09-10 & FY $10-11$ & FY 11-12 & FY 12-13 & FY 13-14 & TOTAL \\
\hline $\begin{array}{l}\text { Budget Outlay } \\
\text { (In Rs Crore) }\end{array}$ & 11300 & 12000 & 30000 & 39100 & 40100 & 31000 & 30287 & 33000 & 226787 \\
\hline $\begin{array}{l}\text { Central Release } \\
\text { (In Rs Crore) }\end{array}$ & 8640.85 & 12610.39 & 29939.60 & 33506.61 & 35768.95 & 29189.77 & 30009.96 & 32743.68 & 212409.8 \\
\hline $\begin{array}{l}\text { Total available } \\
\text { fund } \\
\text { (In Rs. Crore) }\end{array}$ & 12073.55 & 19305.81 & 37397.06 & 49579.19 & 54172.14 & 48805.68 & 45051.43 & 42265.45 & \\
\hline $\begin{array}{l}\text { Expenditure } \\
\text { (In Rs. Crore) } \\
\text { [\% against } \\
\text { available funds] }\end{array}$ & \begin{tabular}{r|}
8823.35 \\
{$[73 \%]$}
\end{tabular} & $\begin{array}{r}15856.89 \\
{[82 \%]}\end{array}$ & $\begin{array}{r}27250.10 \\
{[73 \%]}\end{array}$ & $\begin{array}{r}37905.23 \\
{[76 \%]}\end{array}$ & $\begin{array}{r}39377.27 \\
{[73 \%]}\end{array}$ & \begin{tabular}{r|}
37072.82 \\
{$[76 \%]$}
\end{tabular} & $\begin{array}{r}39657.04 \\
{[88 \%]}\end{array}$ & $\begin{array}{r}37468.65 \\
{[89 \%}\end{array}$ & 243411.4 \\
\hline $\begin{array}{l}\text { Expenditure on } \\
\text { Wages } \\
\text { (In Rs. Crore) }\end{array}$ & $\begin{array}{r}5842.37 \\
{[68 \%]}\end{array}$ & $\begin{array}{r}10738.47 \\
{[70 \%]}\end{array}$ & $\begin{array}{r}18200.03 \\
{[69 \%]}\end{array}$ & $\begin{array}{r}25579.32 \\
{[70 \%]}\end{array}$ & $\begin{array}{r}25686.53 \\
{[68 \%]}\end{array}$ & $\begin{array}{r}24306.2 \\
{[70 \%]}\end{array}$ & $\begin{array}{r}27128.36 \\
{[72 \%]}\end{array}$ & $\begin{array}{r}26096.81 \\
{[74 \%]}\end{array}$ & $\begin{array}{r}163578.09 \\
{[70 \%]}\end{array}$ \\
\hline $\begin{array}{l}\text { Expenditure on } \\
\text { Material } \\
\text { (In Rs. Crore) }\end{array}$ & $\begin{array}{r}2758.77 \\
{[32 \%]}\end{array}$ & $\begin{array}{r}4617.47 \\
{[30 \%]}\end{array}$ & $\begin{array}{r}8100.89 \\
{[31 \%]}\end{array}$ & $\begin{array}{r}11084.49 \\
{[30 \%]}\end{array}$ & $\begin{array}{r}11891.09 \\
{[32 \%]}\end{array}$ & $\begin{array}{r}10650.48 \\
{[30 \%]}\end{array}$ & $\begin{array}{r}10403.31 \\
{[28 \%]}\end{array}$ & $\begin{array}{r}9159.32 \\
{[26 \%]}\end{array}$ & $\begin{array}{r}68665.82 \\
{[30 \%]}\end{array}$ \\
\hline
\end{tabular}

Figure: I Describing Financial Achievement of MGNREGA Year Wise.

The main objective of the MGNREGA is to meet employment demand. In 2008-09, 4.51 crore households were provided employment and in 2015-16, 4.81 crore households were provided employment and 253.14 crore person days of employment generated including 41.74 crore of tribal person days in financial year of 2015-16. Being self targeting in nature the programme had high work participation from marginalized groups like SC/ST (38\%), Women (53\%) in 2012-13. This scheme has 
helped in strengthening the natural resource base as in 2012-13, 64.54 lakh works were undertaken, of which $58 \%$ for water conservation, $12 \%$ for the provision of irrigation facility to land owned by SC/ST/BPL and IAY beneficiaries, $18 \%$ for rural connectivity and $8 \%$ for land development. With a view to universalize the system of wage payments through individual accounts, it has been recommended to all states to disburse wages through Post Offices and Bank Accounts. Total 64292719 numbers of Individual bank accounts and 7821885 number of joint accounts of totaling rupees 2360147.06 in lakh has been disbursed( as per MIS) through bank and through post offices of 1.83 crore a sum of rupees 3821.8 crore of wages has been disbursed in the financial year of 2015-16 thereby taking financial inclusion of poor into account. During the financial year 2013-14 the average person days of employment per household is 46 day. Total number of active women workers \& tribal workers are $520.47 \& 185.91$ lakh respectively (FY: 2015-16, source MIS NREGA) for reference please see figure: II.
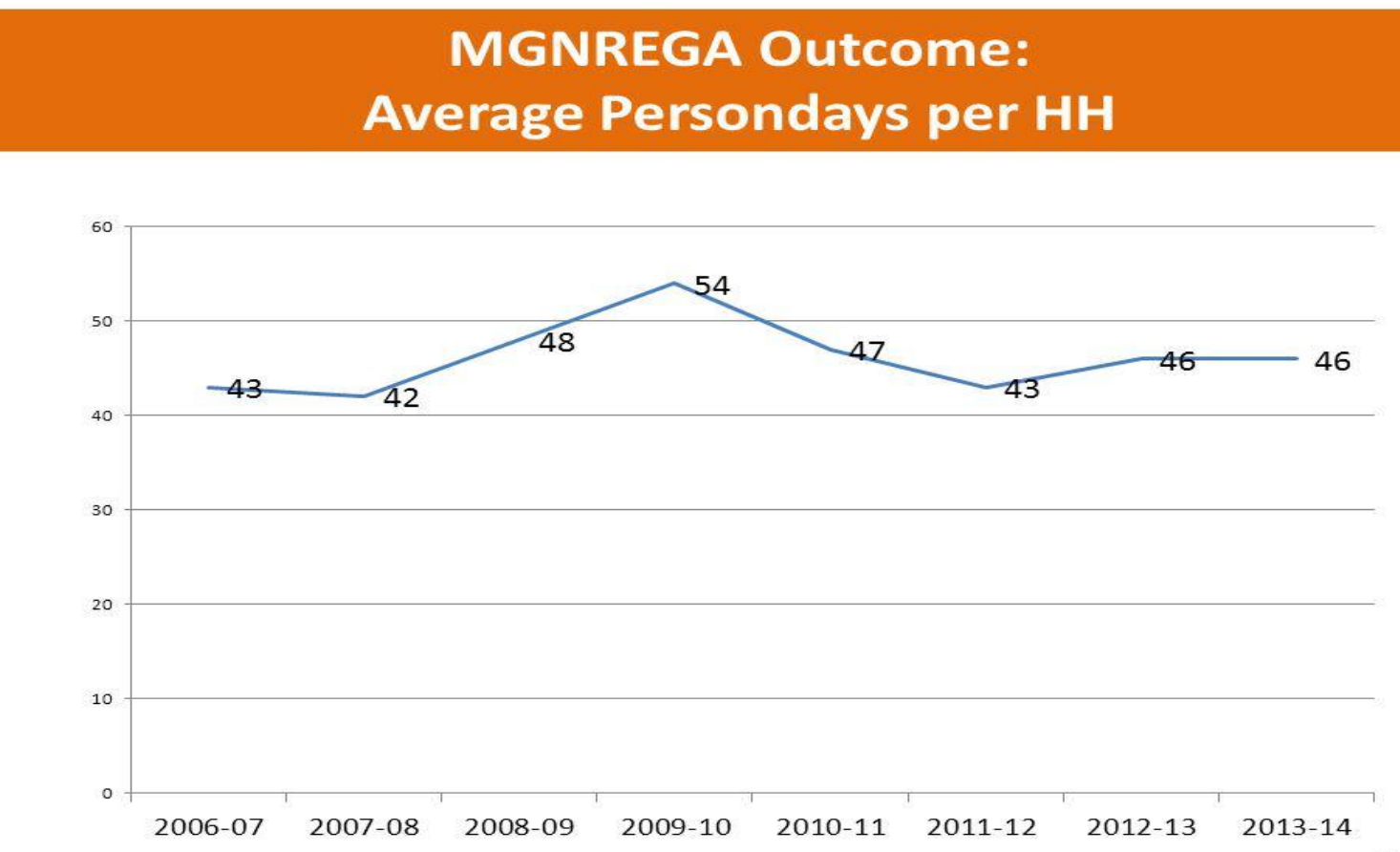

Now we can see the socio-economic indicators of the tribal people: Figure: III

Important Socio-Economic Indicators of General and ST Population in India:

\begin{tabular}{|l|l|l|l|}
\hline S.No & Socio-economic indicators & General Population STs \\
\hline 1. & Population (\%) & 74.6 & 8.2 \\
\hline & (i) Rural population (\%) & 71.1 & 91.2 \\
\hline & (ii) Urban population (\%) & 28.9 & 8.8 \\
\hline 2. & Sex Ratio & 933 & 978 \\
\hline 3. & Total Fertility Rate & 2.66 & 3.06 \\
\hline
\end{tabular}




\begin{tabular}{|l|l|l|l|}
\hline 4. & Effective Literacy Rate (2001) & 64.8 & 47.1 \\
\hline & (i) Male literacy & 78.7 & 59.17 \\
\hline & (ii) Female literacy & 58.17 & 34.76 \\
\hline
\end{tabular}

Gross Enrolment Rate (2003-04)

\begin{tabular}{|l|l|l|l|l|}
\hline & (i) & Class I-V & 108.50 & 123.89 \\
\hline & (ii) & Class VI-VIII & 70.51 & 68.95 \\
\hline & (iii) Class IX-X & 51.65 & 37.16 \\
\hline & (iv) $\quad$ Higher Education & 7.96 & 4.63 \\
\hline 6. & (i) Infant Mortality & 61.8 & 84.2 \\
\hline & (ii) Child Mortality & 22.2 & 46.3 \\
\hline & (iii) Institutional delivery & 40.1 & 17.1 \\
\hline 7. & (i) Percentage of women with anaemia & 47.6 & 64.9 \\
\hline & (ii) Anaemic Children (\%) & 72.7 & 79.8 \\
\hline
\end{tabular}

Basic Amenities

\begin{tabular}{|l|l|l|l|}
\hline 8. & (i) Households with Electricity & 61.4 & 36.5 \\
\hline & (ii) Households with access to drinking water & 14.4 & 28.2 \\
\hline & (iii) Households with Pucca houses & 57.7 & 24.4 \\
\hline $\mathbf{9 .}$ & Occupation Pattern & & \\
\hline & (i) Work participation rate & 30.3 & 49.1 \\
\hline & (ii) Percentage of Main workers to total works & 80.2 & 68.9 \\
\hline & (iii) Cultivators & 32.5 & 44.7 \\
\hline & (iv) Agricultural labourers & 20.7 & 36.9 \\
\hline & (v) Other occupations & 42.2 & 16.3 \\
\hline $\mathbf{1 0 .}$ & (i) Poverty Ratio Rural Population (\%) (1999-2000) & 27.11 & 45.86 \\
\hline & (ii) Poverty Ratio Urban Population (\%) (1999-2000) & 23.65 & 34.75 \\
\hline
\end{tabular}

Due to the backwardness and low socio-economic development among STs, Government has made affirmative policies, Programmes and enacted laws. There are many Constitutional safeguards for the welfare, development and protection of STs in the country besides National Commission, $5^{\text {th }}$ and $6^{\text {th }}$ 
Schedule for the protection and administrative dispensation of tribals in the Central Indian States and North-Eastern Region States, "The Provision of Panchayats (Extension to the Scheduled Areas) Act, 1996 which confers special powers to Gramsabha in $5^{\text {th }}$ Scheduled Areas, "Forest Rights Bill", "Land Rehabilitation \& Resettlement Policy". Though these Constitutional provisions are in place the effective implementation of these in letter and spirit by the State is a great impediment for the welfare and development of the SCs and STs in the country. In spite of the many affirmative actions, tribals in India face insurmountable problems due to their low socio-economic conditions, poverty, unemployment, and displacement, and indebtedness, lack of opportunities, accessibility and awareness of the government programmes. Coupled to this, the government and private industrial establishments have initiated mega projects of mining, hydro-electric, industry, business, roads and transport which is leading to the loss of traditional land ownership and livelihood opportunities. This is resulting in large scale migration of rural tribal to urban areas in search of livelihoods either temporarily or on permanent basis which in turn resulting into the disturbances of their traditional socio-psychological family relationship, network of neighborly relationships and the adoption of new urban culture. Human Migration and in particular tribal migration with its implications is becoming an important socio-economic problem for the policy makers and government to undertake welfare and development activities.

\section{Tribal Migration:}

Tribal society is largely egalitarian and tribal women have been equal partners with tribal men in the contribution to household economy. Quite often their women do more physical labour in their agricultural fields and forest than that of the tribal men. Tribal women have usually enjoyed a higher social status in their own communities than Indian women in general. Some of the tribes in sub-Himalayan regions like Khasis of Meghalaya are matriarchal. As indicated earlier the socio-economic profile of tribals especially the tribal women is quite low compared to tribal men and general population and this is also associated with poor nutritional and health status among the tribals. Tribal's are engaged in various occupations like hunting, fishing, gathering of forest products, shifting cultivation to settled agriculture, rural crafts and artisans. A very few tribal groups are engaged in non-agricultural activities as mendicants, bards, pastoralists leading a semi-nomadic to nomadic life. Besides routine household work, the tribal women work in the agricultural fields, forests for long hours. The overall output if seen in terms of number of hours of work is low. Their schedule of long working hours continues even during pregnancy, natal and postnatal stages. They have a negative energy balance, high morbidity rate, and low child survival rate. They suffer from taboos and superstitions and remain deprived of the benefits from existing development and welfare programmes.

Most of the natural resources including minerals are located in tribal areas. Tribals are being alienated from their land and forest due to the ongoing de forestation, hydro-electric power generation, industrial growth and mining activities The natural resources are being exploited in a way, which leads to a process of gradual displacement and denying the basic right of livelihood to the Adivasis. Massive investment in construction of dams, power plants, industrialization and mining create wealth to the nation and employment opportunities to various people but all this is hardly of any benefit to the tribals rather it leads to their social and cultural deprivation, land alienation, destruction of environment and displacements, which is often without any rehabilitation. As per the Ministry of Rural Development large scale tribal land continues to be alienated in the States of Andhra Pradesh (2.79 lakh acres), Madhya Pradesh (1.58 lakhs acres), Karnataka (1.3 lakh acre), Gujarat (1.16 lakh acres) during the beginning of the Tenth Plan and the settlement cases are not being disposed of easily. About 20.50 lakh persons inhabiting in forest areas most of whom are tribals inhabiting for generations together have been deprived of their lands and traditional rights. Due to the recent enactment of the "The Scheduled Tribes and Other Traditional Forest Dwellers (Recognition of Forest Rights) Act, 2006" the forest dwelling tribals have claimed forest land and the state governments could able to give lands to only about 1.50 lakh persons. Migration to towns and cities often negatively influences the 
tribal culture and identity. In addition to dam construction and mining there are problems with access to forest resources where tribals neither have control nor any kind of participation in forests, which once were their abode and were one of the major sources of their livelihood.

Historically disadvantaged communities such as the Scheduled Castes, Scheduled Tribes and Other Backward Castes (OBCs) are heavily represented in migration. Before independence the out-migration of tribals to the urban and industrial cities was very meager. This was due to the physical environment constraints. The limited needs of the tribals also did not motivate them to come to cities. After independence the picture has changed considerably. The change has been due to the implementation of Five-Year Plans and Annual Plans which resulted in tribal development. The directive principles of the state policy have made special programmes for the social, political and economic development of the tribals with the objective of integrating them at the various levels of rural and urban communities. Secondly, the safeguards provided by the constitution have made them available great opportunities of education, entrepreneurship and jobs in Government service and in organised sector. Reservations in service have opened up new avenues for the tribals. The process of social mobility has given a high status to the tribal migrants. The implementation of development schemes for the tribals by different government departments has created a favourable ground for the immobile tribal population to undertake out migration to big cities. The migration was forced as the British employed tribal labour to work in the West Bengal tea gardens. However, since the latter half of the $20^{\text {th }}$ Century, tribal people from these areas have started migrating voluntarily to earn their livelihood. In the last century, a noticeable change was visible in the nature and pattern of tribal migration. Between 1950 and 1980, tribal people migrated to the rural areas of Bihar, West Bengal mainly to work as agricultural labour (Mosse et al., 1997). But from 1980 onwards, they started migrating to bigger cities like Delhi, Kolkata and Mumbai. Another new feature of tribal migration from these states in recent years has been the large - scale migration of single women to cities in search of livelihood, which is a subtle change from the earlier migration patterns when only the men migrated to urban centres. Tribal families nowadays are driven by poverty to send unmarried daughters to cities in search of work. Single women and tribal girls are however, prone to exploitation not only by employers but also by anti-social elements.

A range and combination of push and pull factors drive circular migration particularly the tribals and tribal women in particular. Circular migration, or rural-urban migration, is emerging as a dominant form of migration amongst STs in India. Earlier studies reported that, an estimated 30,000 labourers migrate from Bolangir District in western Orissa every year (Deshingkar et.al 2008). The remote droughtprone and forested tribal areas of Madhya Pradesh show similarly high levels of out-migration. In the tribal districts of southern Madhya Pradesh, 65\% of households included migrants. In Jharkhand, one study $\mathrm{r}$ e p o r t e d t h a t, of twelve villages found that one-third of the households had at least one member migration. There are extremely high rates of migration among tribals from southern Rajasthan who migrate to Gujarat to work in seed cotton farms and textile markets. The incidence of migration was clearly growing in the area as a few years later another study in the same area found that in many villages up to three-quarters of the population were absent between November and June.

Tribal migrants have found jobs in factories, agro-processing plants or working as porters, domestic servants, bus cleaners, rickshaw pullers, street hawkers, petty traders, construction workers and domestic workers. Migrants are often willing to take on jobs that others cannot or do not want to do (those that are dirty, degrading and dangerous). The work is commonly poorly paid and insecure but it is very attractive to those from marginal areas where wages are too low to make a living. Income is one driver, with people migrating in search of paid employment. Early studies also reported that internal migration can lead to positive change in both sending and receiving areas (Deshingkar et.al 2006). Migration can help to reduce poverty or to halt the slide into poverty. It also helps tighten rural labour markets. There are many negative impacts of migration like loss of identity, culture, security, acute shortage of labour and high dependency ratios in sending areas. Mass male migration can lead to worsening poverty. People who are 
away for a long time may lose access to natural resources and lose their voice in community led decisionmaking. Migration can also have a negative effect on collective action and natural resource management.

\section{Justification of the Study:}

It has been observed that large number of educated, uneducated and illiterate tribal women from Jharkhand, Chhattisgarh, Orissa and West Bengal migrate to different parts of the country and metropolitan city like Delhi, Mumbai, Kolkata are their major destinations for searching some gainful employment/casual labour in the unorganized sector and as household maids for their livelihood. They are often exploited physically and sexually. The above context, nature of varied data sets, regional and seasonal variation, different types and forms of migration like inter-state cross migration, circular migration, occupational migration, short-term migration, long-term migration, migration caused by displacement and gender migration etc. particularly among tribals and women tribal folks indicate that there is a still a dearth of data and detailed analysis and probe is required to understand the tribal migration. The reasons for their exodus need to be studied in detail given the large number development programmes like National Rural Employment Guarantee Act (NREGA), Jawahar Rojgar Yojana (JRY), Employment Assurance Scheme (EAS), Food for Work Programme (FFW), Prime Minister Gramin Swarojgar Yojana (PMGSY), Swarna Jayanti Gramin Swarojgar Yojana (SGSY). Under the proposed study it is planned to find the reasons for their migration and to document how and where they migrate, their living conditions prior to migration and at their place of migration, what they feel about their future, whether they know the development programmes being implemented for their benefit, what is their health status, their vertical job mobility, the impact of the migration on their socio-economic life pattern at individual and community level, agencies involved and all other related aspects particularly the tribal women migrants. The study will focus only on the Sarenga Development Block in Bankura district of west Bengal state. The findings of the study will be utilized in putting forward various suggestions which can help the policy makers to undertake various development and welfare interventions among these tribal groups.
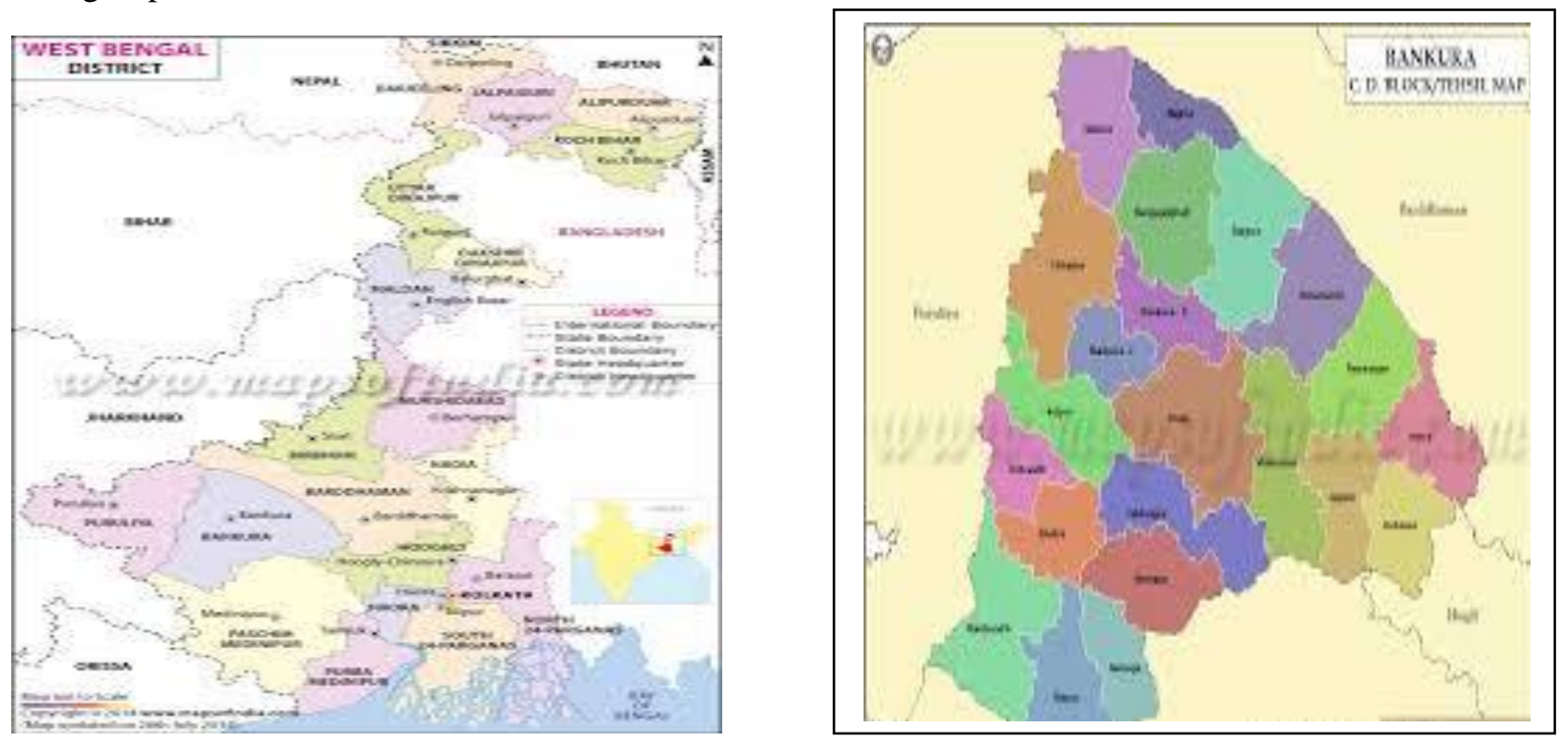

Image of West Bengal \& Bankura District 


\section{MGNREGA: A Brief Overview}

In India for rural development various strategies and programmes through Government are still forwarded, in which MGNREGA has precious contribution. NREGA Act was passed in 2005 that guaranteed 100 days wage of employment in a year to every rural house. Government of India has renamed the NREGA as MGNREGA on 2nd October 2009. On 2, Feb, 2006 it was launched in 200 select districts and was extended to 130 additional districts during 2007-08. It is now implemented in 645 districts of the country. Under MGNREGA work is provided for about 100 days for every households reside in villages. In this case, rural people have to gone through a process for getting employment. First of all, every rural household supposed to get registered them to local Gram Panchayat for seeking employment, then within 15 days job cards containing photographs are issued to all entitled applicants. After getting job cards, work is allotted to job card holders within 15 days. In case, failed to provided work wage is given as per day schedule. The nature of MGNREGA work is unskilled manual work and this is targeted to enhance livelihood security of every rural people by providing Guaranteed Wage Employment for 100 days and in that process of employment generation durable assets are build up as it focus the work of water and soil conservation, afforestation and land development, irrigation, rural connectivity, flood protection, drought proofing etc. the projects for villages are recommended by gram sabha approved by jila panchayat, where as 50 percent works should be implemented by gram panchayat. Panchayati Raj Institutions (PRIS) plays principal role over planning and implementation. Some of the definitions of the MGNREGA are as follows:

[1]. According to C.P. Chandrasekhar and Jayati Ghosh, "The NREGA is necessarily "inclusive" at the most basic level in the economic terms, because is self-targets those who are willing to engage in arduous physical work for a daily wage, in other words the poorest sections of society. But it is also socially inclusive as well, that, it disproportionately involves women, SCs and STs as workers in the scheme."

[2]. According to many analysts, "the programmme is boosting the purchasing power of the rural poor and has led to a stable income for the rural population. The most eligible rural families that the NREGA hope to benefit are those of the landless-labours as well as the small and marginal farmers." 


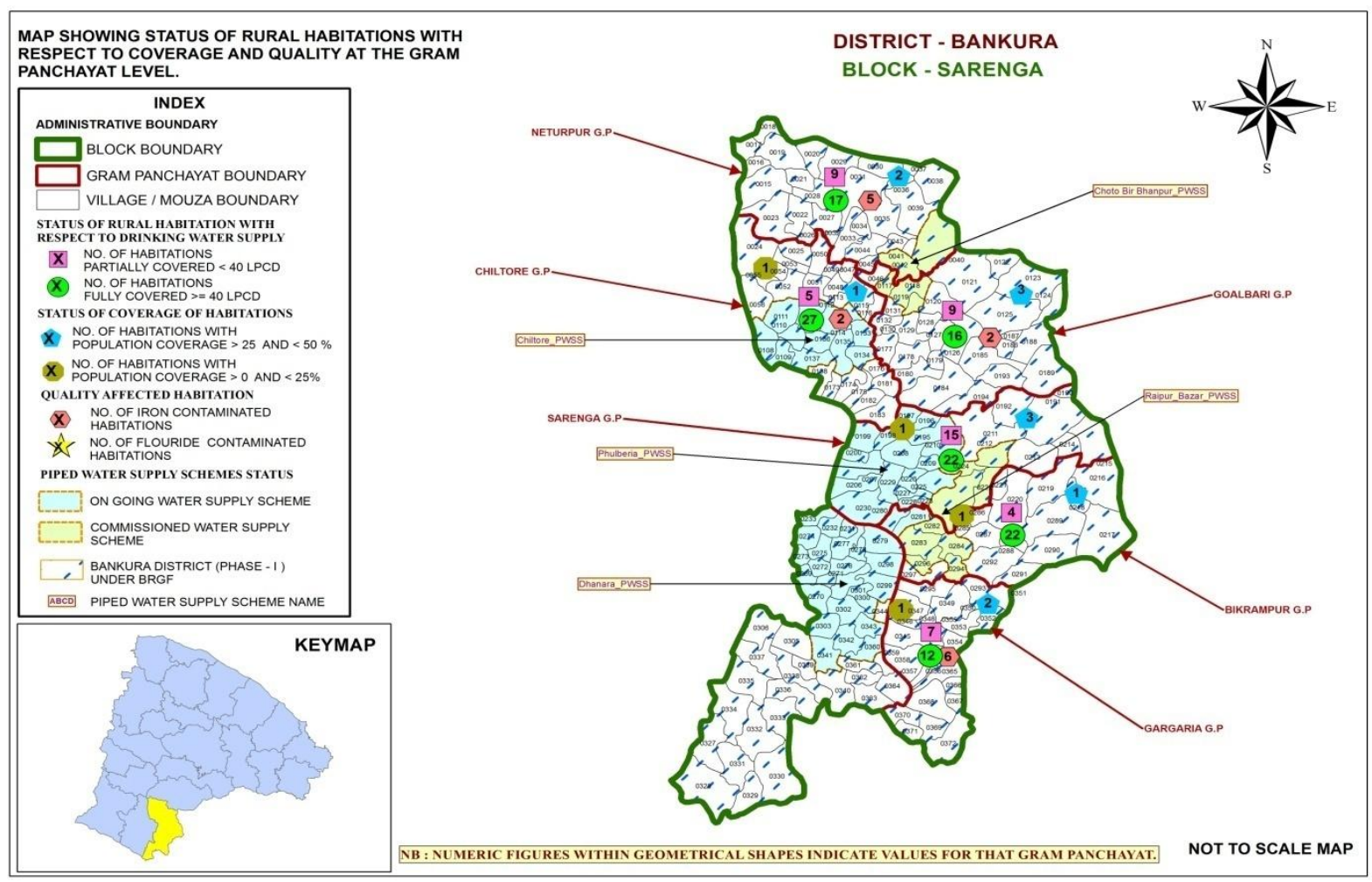

5. Profile of the Study Area:

The study was conducted in the south-western region of the Bankura district of West Bengal. Bankura is one of the 19 districts of West Bengal. It comes under the "Junglemahal Area". It is located in the western extremity of Bankura that lies between $22^{\circ} 46^{\prime} 0.12^{\prime \prime} \mathrm{N}$ to $22^{\circ} 76^{\prime} 67$ North latitudes and $87^{\circ} 1^{\prime} 59.88$ and $87^{\circ} 0333^{\prime}$ East longitudes. Its total geographical area is $223.78 \mathrm{sq} \mathrm{Km}$. The population of the Block is 106808 out of which the tribals constitute around 20407 having percentage of 19.11\%" (2011, Census). In the North, there is Simlapal Block and Paschim Midnapur district situated in the south \& in the East Side of the block. Kansai River makes a boundary in the west $\&$ in the southern side. Sarenga is under the Constituency Assembly of Raipur 250(ST). There is six Gram Panchayat under the block of Sarenga. In the north there is Neturpur GP \& in the South is Gargaria. East part of the Block is under Goalbari GP \& partly Bikrampur GP, and western part is under Chiltore \& Partly Sarenga Gram Panchayat. Total No of Household of the Block is 25333, out of them 13260 nos are under BPL.

\section{Short Profile: Sarenga Development Block}

Name of the Block: Sarenga

No. of Gram Sansad: 80

No. of village: 218

No. of Mouza: 166

No. of Depopulated Mouza: 13

No. of Populated Mouza: 153

No. of Household: 19765

Total area of Block 22393.64 Hactre 
IRA-International Journal of Education \& Multidisciplinary Studies

\begin{tabular}{|l|l|l|l|l|l|}
\hline G.P & Area (Hect) & Male & Female & Others & Total \\
\hline Bikrampur & 3859.79 & 6794 & 6772 & 1 & 13567 \\
\hline Chiltore & 3178.95 & 8361 & 7888 & 0 & 16249 \\
\hline Gargaria & 2541.28 & 9600 & 9122 & 0 & 18722 \\
\hline Goalbari & 4379.8 & 7830 & 7733 & 0 & 15563 \\
\hline Neturpur & 3867.08 & 9101 & 8712 & 0 & 17813 \\
\hline Sarenga & 4566.74 & 12461 & 12398 & 1 & 24860 \\
\hline
\end{tabular}

/ S.C S.T

\begin{tabular}{|l|l|l|}
\hline Sex & Scheduled Caste & Scheduled Tribe \\
\hline Male & 13530 & 9412 \\
\hline Female & 12913 & 9436 \\
\hline
\end{tabular}

Scores of tribal and rural development programmes have been implemented in the Sarenga Development Block since independence but, it is very unfortunate that tribals' especially tribal women of this Block are still not an effective part of these inclusive development policies introduced by our national government. Innocent and ignorant tribals study area in particular are worst victim of displacement, losing their land and livelihood, when the question of livelihood is at stake; they are ultimately forced to migrate to cities and neighboring states in large number The rehabilitation package of the displaced tribals does not solve their miseries. Thus, in this paper an attempt has been made to examine the potencies and loopholes in the existing MGNREA and its impact on tribal women in West Bengal, especially Sarenga Development Block, which are causing 'more alienation than development'.

\section{Research Objective:}

- To examine the impact of Mahatma Gandhi National Rural Employment Guarantee Scheme on Rural Migration.

- To find out the reasons for failure of MGNREGA in reducing rural Migration.

- To examine the determinant factors affecting rural migration.

- To review and synthesis impact of migration of tribals on the said block before and after commencement of MGNREGA.

- To suggest suitable policy measures for improving the strength of the scheme in reducing rural migration.

\section{Research Question:}

- What is the contribution of MGNREGA in reduction of MGNREGA in relation to other competing factors?

- What is relation between MGNREGA \& Migration?

- Could MGNREGA successful in fulfilling its objectives?

\section{Research Methodology:}

\section{Methodology}

The present study is a micro level research on impact of MGNREGS on rural migration. The study is basically an empirical one. In order to achieve the stipulated objectives, the methodology that has been followed in this study is historico-analytical. The historical method has been applied for historical records, information, documents, and file records etc. which are the basis of the study. The analytical method is employed to analyze the facts pertaining to the study. Keeping the objectives and research questions in view, it has been decided to collect relevant data from both primary as well as secondary 
sources. The secondary sources such as books, journals, newspapers, websites etc. were consulted to collect the factual data concerning the study. The primary data have been generated by personal interview method from 200 beneficiaries of MGNREGS as sample sizes from the four selected villages, i.e. 50 households from each village with the using a self prepared structured interview schedule by considering different anxiety dimensions like demographic and socio-economic background of the respondents, household provided 100 days of wage employment, wage rate and wage payments, affect of MGNREGS in labour migration and factors affecting migration from the rural to urban areas. The age limit of the respondents was 20 and above. The study was conducted during the period of March to June 2012. The questions were prepared in English for the sake of convenient but were translated into the local language (Bengali - which is the common language spoken in the district) at the time of their administration for the purpose of eliciting information. Besides, as per the requirements, simple statistical tools like percentage, average and table were applied to analyze the data for the study. Figure-X may be seen:

\begin{tabular}{|l|l|l|l|}
\hline .Sl No & Name of the Unit & Sample size per unit & Total Sample size \\
\hline 1 & Blocks selected & 1 & 1 \\
\hline 2 & Gram Panchayat selected & 4 & 4 \\
\hline 3 & Village per gram panchayat & 1 & 4 \\
\hline 4 & Families per village & 50 & 200 \\
\hline
\end{tabular}

An extensive and intensive field work has been undertaken to make in-depth study of the socio-economic conditions with special reference to the nature and types of migration. Further in-depth study was carried out at Chandrokona, Bankura and Medinipur town where the tribals generally migrate for in search work. 15 tribals were selected randomly therein for primary qualitative and quantitative data in pursuance of the objectives of the study. Thus a total sample size of 200 population universe was covered for the present study. Further, relevant information was also collected from among the social activists, officials connected with the management of forest, village officials, people's representatives and other important persons with the help of detailed open ended discussions and "Focus Group Discussions (FGDs).

\section{Details of Blocks, Villages and Families Surveyed in the Study.}

The numbers of households of the selected village are around fifty. The selected village is fifty years old in settlement at the existing locality. The number of employed households under NREGS is more than 90 per cent. Besides, while selecting the villages, emphasis was given on caste wise representation i.e. Schedule Caste, Schedule Tribe and Other Backward Classes. Please see figure:XI

\begin{tabular}{|l|l|l|l|l|}
\hline \multicolumn{6}{|c|}{ Particulars of Sample Villages. } \\
\hline Name & $\begin{array}{l}\text { Development } \\
\text { Block }\end{array}$ & $\begin{array}{l}\text { Name of the Gram } \\
\text { Panchayat }\end{array}$ & $\begin{array}{l}\text { Caste } \\
\text { Composition }\end{array}$ & $\begin{array}{l}\text { Distance from District } \\
\text { Head Quarter }\end{array}$ \\
\hline Chiltore & Sarenga & Chiltore GP & OBC & $72 \mathrm{~km}$. \\
\hline Andharia & Sarenga & Goalbari GP & SC & $64 \mathrm{~km}$. \\
\hline Asna & Sarenga & Gargaria GP & ST & $73 \mathrm{~km}$. \\
\hline Chingra & Sarenga & Bikrampur GP & ST & $70 \mathrm{~km}$. \\
\hline
\end{tabular}

- Review of literature on NREGA and its impact on migration.

- Collection of primary \& secondary data of out migration from NSS $55^{\text {th }}$ and $64^{\text {th }}$ round \& Census 2011.

- Showing correlation between out migrants and MGNREGA intensity. 


\section{Limitations of the Study:}

The study is limited to following respects: The findings of the study were based on expressed information of 200 selected respondents which may have its own limitations. Possibility of hiding certain facts cannot completely be ignored, although uttermost attention was taken to elicit authentic information.

The technique employed for collection of relevant data was structured interview schedule. Therefore, the findings of the study were limited to this technique only. The scope of the study was limited to four selected villages of Sarenga Development Block of Bankura District of West Bengal. Thus, the conclusions of this study have their own limitations and can be applied elsewhere, with certain precautions

\section{Results and Discussion:}

The attitudes and perception of the respondents have been analyzed with the help of empirical statistical data. The opinions of the respondents collected from the field are presented in the tabular form below. The first three tables are related to demographic and socio-economic profile of the sample respondents and the rest are based on observation of the sample respondents during the field work. The collected data have been analyzed under following five important indicators:

Household provided 100 days of wage employment,

Wage ate and wage payments,

Impact of MGNREGS in rural migration,

Factors affecting rural migration, and

Suggestions to improve the MGNREGS functioning for reducing rural migration

\section{Demographic and Socio-Economic Profile of the Respondents:}

Demographic Characteristics - Age and Sex .

Looking at the demographic profile of the respondents (Table-9.1), out of the total 200 respondents, 63 which constituted 31.50 per cent belonged to the age group of $40-49$ years, followed by 28.50 per cent between the age group of $30-39$ years, 19.50 per cent in the age group of 20 - 29 years and 15 per cent within 50 - 59 years. Though the population above the age of 60 years is considered as old citizens, the study showed that a sizeable number of respondents i.e. 5.50 per cent (11) belonged to above 60 years. From the point of gender differences, male respondents constituted 57.50 per cent (115) while female respondents accounted 42.50 per cent (85) of the total respondents. 15 per cent within 50 - 59 years. Though the population above the age of 60 years is considered as old citizens, the study showed that a sizeable number of respondents i.e. 5.50 per cent (11) belonged to above 60 years. From the point of gender differences, male respondents constituted 57.50 per cent (115) while female respondents accounted 42.50 per cent (85) of the total respondents. 


\section{Demographic Indicators of Respondents:}



Source: Field Survey

\section{Social Characteristics - Caste and Educational Status}

The respondents were basically two types - tribal and non-tribal. The empirical data on caste composition of respondents (Table - 9.1.1) revealed that the caste wise representation of respondents was almost equal. The percentage of tribal and non - tribal respondents stood at 49.50 per cent and 50.50 per cent respectively. The caste group classification also showed that 41.50 per cent of the total respondents belonged to Other Backward Classes (OBC) followed by Scheduled Caste (5.50 per cent) and other communities $(3.50$ per cent). Non - tribal respondents stood at 49.50 per cent and 50.50 per cent respectively. The caste group classification also showed that 41.50 per cent of the total respondents belonged to Other Backward Classes (OBC) followed by Scheduled Caste (5.50 per cent) and other communities (3.50 per cent).

15: Social Characteristics of Respondents.

\begin{tabular}{|c|c|c|c|c|c|c|c|c|c|c|}
\hline \multirow{3}{*}{ Caste } & \multicolumn{6}{|c|}{ Name of the Village } & & & & \\
\hline & \multicolumn{2}{|c|}{ Chiltore } & \multicolumn{2}{|c|}{ Andharia } & \multicolumn{2}{|c|}{ Asna } & \multicolumn{2}{|c|}{ Chingra } & \multicolumn{2}{|c|}{ Total } \\
\hline & & & & & & & & & & \\
\hline & No & PC & No & PC & No & PC & No & PC & No & PC \\
\hline Tribal & Nil & Nil & 1 & 2.00 & 50 & 100 & 48 & 96.00 & 99 & 49.50 \\
\hline Non-Tribal & 50 & 100 & 49 & 98.00 & Nil & Nil & 2 & 4.00 & 101 & 50.50 \\
\hline Total & 50 & 100 & 50 & 100 & 50 & 100 & 50 & 100 & 200 & 100 \\
\hline SC & 9 & 18.00 & Nil & Nil & Nil & Nil & 2 & 100 & 11 & 5.50 \\
\hline
\end{tabular}


IRA-International Journal of Education \& Multidisciplinary Studies

\begin{tabular}{|l|l|l|l||l|l|l|l|l|l|l||}
\hline OBC & 34 & 68.00 & 49 & 100 & Nil & Nil & Nil & Nil & 83 & 41.50 \\
\hline Others & 7 & 14.00 & Nil & Nil & Nil & Nil & Nil & Nil & 7 & 3.50 \\
\hline $\begin{array}{l}\text { Sducational } \\
\text { Status }\end{array}$ & No & PC & No & PC & No & PC & No & PC & No & PC \\
\hline Literate & 19 & 38.00 & 40 & 80.00 & 16 & 32.00 & 21 & 42.00 & 96 & 48.00 \\
\hline Illiterate & 31 & 62.00 & 10 & 20.00 & 34 & 68.00 & 29 & 58.00 & 104 & 52.00 \\
\hline Total & 50 & 100 & 50 & 100 & 50 & 100 & 50 & 100 & 200 & 100 \\
\hline ME Passed & 17 & 89.47 & 20 & 50.00 & 13 & 81.25 & 16 & 76.19 & 66 & 68.75 \\
\hline HSLC Passed & 2 & 10.53 & 11 & 27.50 & 3 & 18.75 & 5 & 23.81 & 21 & 21.88 \\
\hline HS Passed & Nil & Nil & 8 & 20.00 & Nil & Nil & Nil & Nil & 8 & 8.33 \\
\hline Graduate & Nil & Nil & 1 & 2.50 & Nil & Nil & Nil & Nil & 1 & 1.04 \\
\hline Post-Graduate & Nil & Nil & Nil & Nil & Nil & Nil & Nil & Nil & Nil & Nil \\
\hline Total & 19 & 100 & 40 & 100 & 16 & 100 & 21 & 100 & 96 & 100 \\
\hline
\end{tabular}

Educational status is a major socio-economic indicator of a family. Hence, the educational background of the respondents has been recorded during the course of study (Table - 9.1.1) which showed a vivid picture of educational attainment of the respondents. For the purpose of the study, a person who simply could write and sign his/her name was considered as literate. However, the analysis does not show any optimistic picture of literacy rate (48 per cent) in the selected areas under study. Significantly, the majority (68.75 per cent) of the respondents studied up to ME School. The literary rate up to HSLC level stood at 21.88 per cent while 8.33 per cent represented HS level and 1.40 per cent studied up to graduate level.

\section{Economic Characteristics - Occupation and Annual Income}

The major occupation of the respondents was farming (Table-9.1.2). Out of 200 interrogated respondents, the highest 53.50 per cent (107) were found as cultivators followed by house wife (31.50 per cent) and labourers (9.00 per cent). Though agriculture was the main occupation of the respondents, it has been observed that certain trends of changes have come up in to their occupations. Now-a-days due to the opening up of new avenues of earnings, many of the respondents apart from agriculture, have taken up allied sources as their occupations such as engaging themselves in doing private service ( 0.50 per cent); fishermen (5.00 per cent); business ( 0.50 per cent). 
IRA-International Journal of Education \& Multidisciplinary Studies

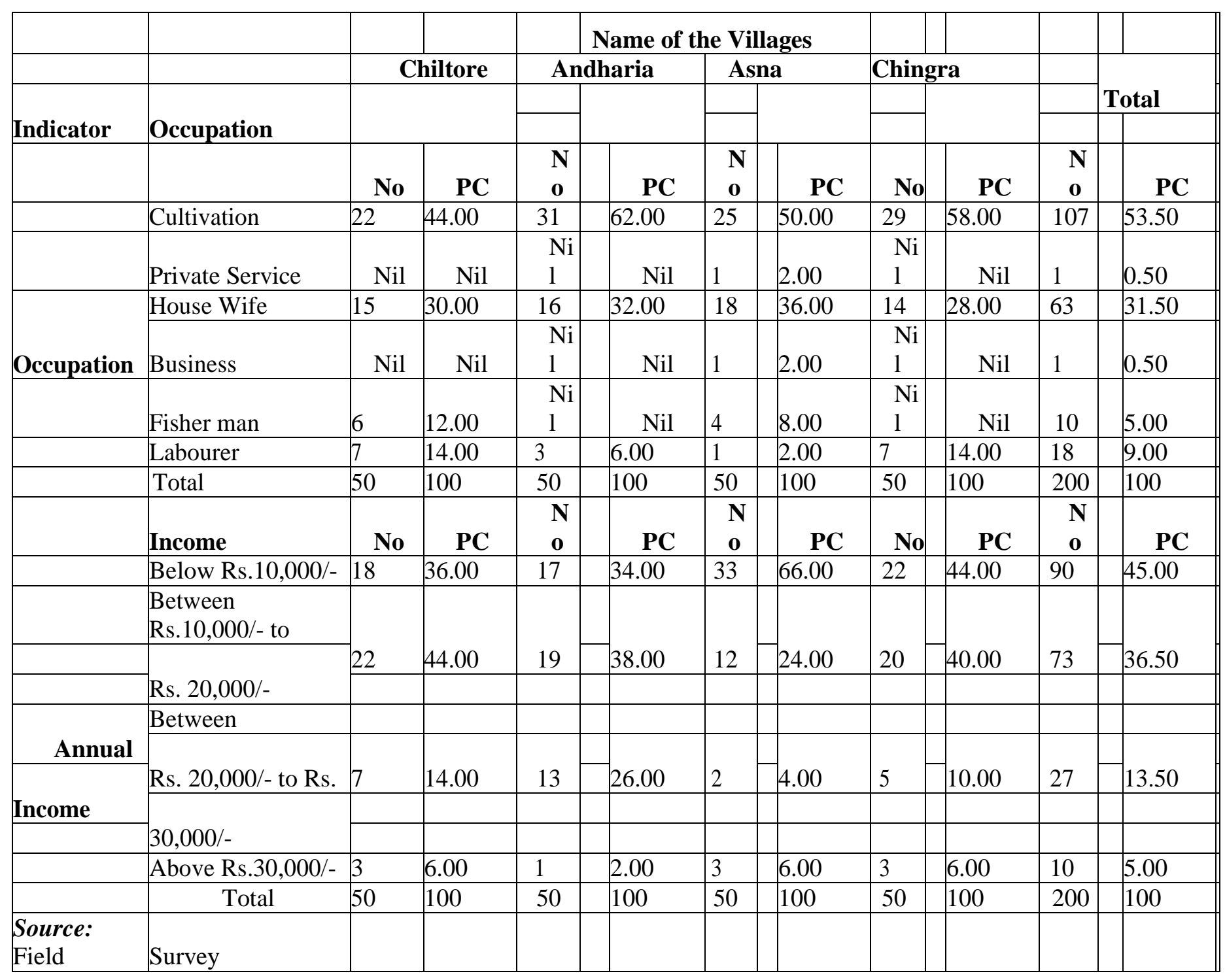

The field study suggested that most of the beneficiaries came from economically poor background to engage under MGNREGS. Majority of the respondents (45.00 per cent) belonged to the lower income group i.e. below Rs. 10,000/ per annum, while the respondents who came from high income group (30,000/ per annum) constituted 5.00 per cent. The respondents between the income group of Rs. 10,000/to Rs. 20,000/ per annum constituted 36.50 per cent followed by 13.50 per cent within the income level of Rs. 20,000/- to Rs. 30,000/-. Thus, different income group of families were engaged in MGNREGS. However, majority of the respondents belonged to the lower income group.

\section{Effect of migration:}

- In case of nuclear family full family migrate with infant, children.

- Usually they form a group from the same community or from the neighbouring communities: the relatives from different places are also there.

\section{Perception of the Respondents:}


The statistical data derived from the field revealed that the MGNREGS failed to provide the targeted 100 days of wage employment to each rural household in a financial year in selected villages under study (Table-9.2). 91 per cent of the total respondents viewed that MGNREGS could not provide 100 days of guaranteed employment while 96.50 per cent very clearly stated that one hundred days of wage employment round the year was insufficient for the rural unemployed.

Responses of the respondents:

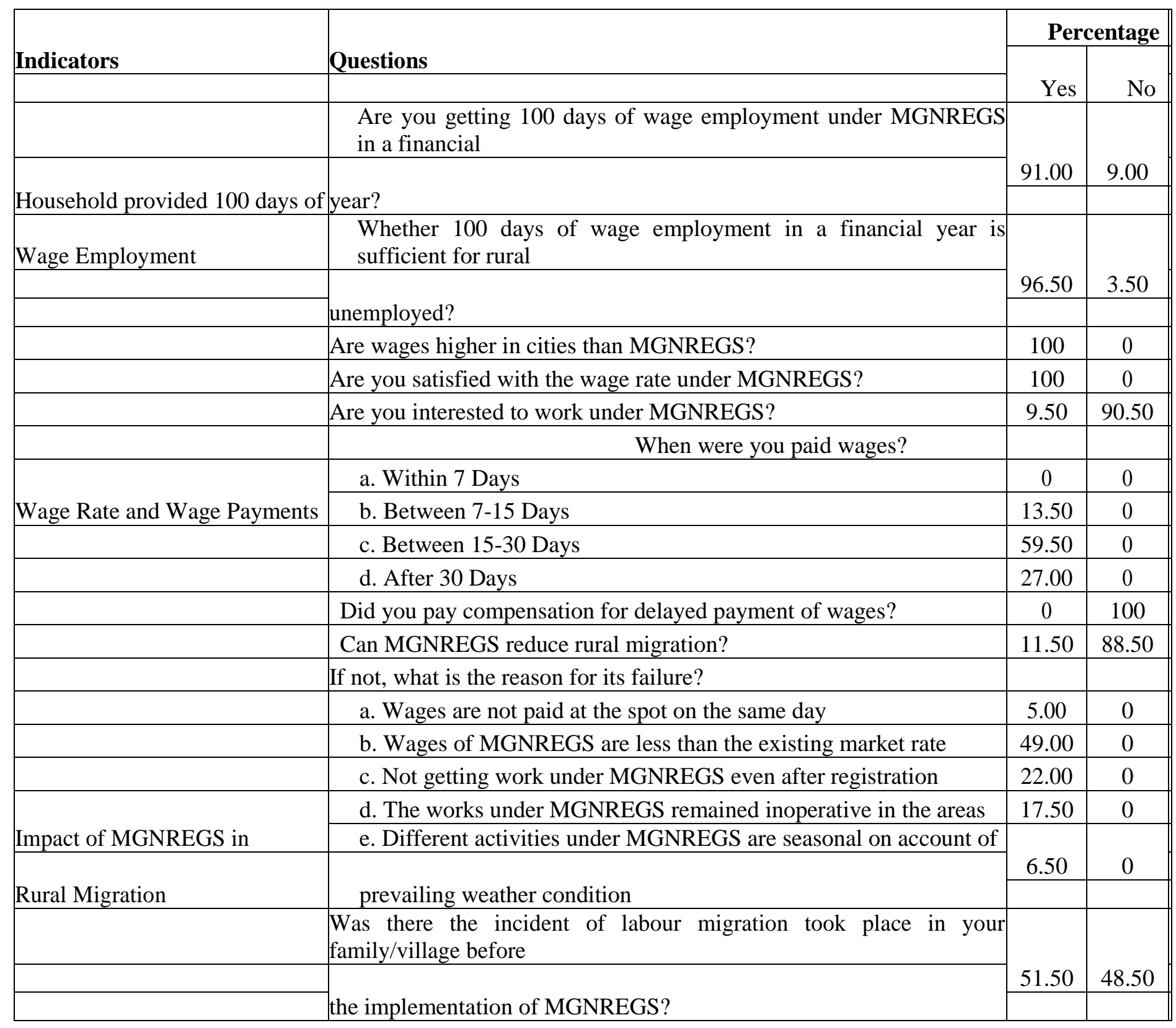


IRA-International Journal of Education \& Multidisciplinary Studies

\begin{tabular}{|c|c|c|c|c|}
\hline & $\begin{array}{l}\text { Did any of your family/village members migrate out of job after the } \\
\text { implementation } \\
\text { of MGNREGS? }\end{array}$ & 59.00 & 41.00 \\
\hline & & $\begin{array}{l}\text { Do any of your family/village members migrate back to village to } \\
\text { work under } \\
\text { MGNREGS? }\end{array}$ & 0 & 100 \\
\hline & & $\begin{array}{l}\text { Does the rural migration decline after implementation of } \\
\text { MGNREGS? }\end{array}$ & 33.00 & 67.00 \\
\hline \multirow{7}{*}{\begin{tabular}{|l} 
Factors \\
Migration
\end{tabular}} & \multirow{7}{*}{ Rural } & \multicolumn{3}{|l|}{$\begin{array}{l}\text { Which of the following factors help in rural } \\
\text { migration? }\end{array}$} \\
\hline & & a. Job or employment & 73.50 & 0 \\
\hline & & b. Marriage & 2.50 & 0 \\
\hline & & c. Education & 10.00 & 0 \\
\hline & & d. Health or medical facilities & 6.00 & 0 \\
\hline & & e. Amenities & 1.00 & 0 \\
\hline & & f. Others & 7.00 & 0 \\
\hline $\begin{array}{l}\text { Suggestions to } \\
\text { MGNREGS } \\
\text { Functioning for Reducir } \\
\text { Migration }\end{array}$ & $\begin{array}{l}\text { Improve } \\
\text { g Rural }\end{array}$ & $\begin{array}{l}\text { Following suggestions were forwarded by the respondents for } \\
\text { reducing rural } \\
\text { 1. Wages should be paid on the spot in time. } \\
\text { Present target of } 100 \text { days of wage employment per household } \\
\text { should be increased to } \\
\text { minimum } 150 \text { days. } \\
\text { The wage rate under MGNREGS should have parity with market } \\
\text { rate. } \\
\text { All works under NREGS should be implemented well planned } \\
\text { ahead of time. } \\
\text { Different activities under MGNREGS were seasonal on accou } \\
\text { weather condition. } \\
\text { Therefore, the implementing authorities should start the MGNRI } \\
\text { during lean season } \\
\text { as well. } \\
\text { Awareness programmes should be organized to sensitise the } \\
\text { common people. }\end{array}$ & $\begin{array}{l}\text { on } \\
\text { per } y \\
\text { and of } \\
\text { EGS p } \\
\text { and }\end{array}$ & $\begin{array}{l}\text { vailing } \\
\text { ramme }\end{array}$ \\
\hline
\end{tabular}

Source: Field Survey

In regard to comparison of wages under MGNREGS with cities, 100 per cent respondent opined in the affirmative. All the respondents frankly admitted that the wage rate under MGNREGS was sizeably lower than the prevailing market rate (Rs. 250 or more than that per day) for which 90.50 per cent interviewees reported that they were not interested to work under the scheme.

As per NREGA - 2005, wages are to be paid every week or in case, not later than a fortnight after the date on which such work was done. The Act also ensures that if the wages are not paid in time, the labourers are entitled compensation as per the provisions of the Payment of Wage Act, 1936. By and large, 59.50 per cent respondent asserted that they had paid wages between 15 to 30 days. Moreover, 100 per cent respondent viewed that no compensation was paid to them for delayed payment. 
In replying to the question about whether MGNREGS could reduce rural migration, 88.50 per cent replied that the scheme failed to reduce rural migration. Regarding the reasons for failure of MGNREGS in reducing rural migration, different types of opinion were observed of which majority (49 per cent) hold the view that wages under MGNREGS was sizeably lower than the existing market rate. They opined that before (51.50 per cent) and after (59 per cent) implementation of MGNREGS, the incident of migration to nearby cities or town took place in their localities. Besides, 100 per cent interviewees reported that no family/village members migrated back to village to work under MGNREGS. 67 per cent of the respondents responded that the rural migration was not declined after the implementation of MGNREGS. Regarding factors affecting the rural migration, an absolute majority ( 73.50 per cent) of the respondents did not have satisfactory comments and viewed that many young people migrated from rural to nearby urban areas in search of job or employment. In light of these analyses, the following measures are suggested which may be considered by the implementing authorities and policy planners for securing improvement of MGNREGS functioning for reducing rural migration: Wages should be paid timely. The wage rate should be enhanced keeping parity with the existing market rate. Present target of 100 days of wage employment should be increased to minimum 150 days to every rural household in a financial year. All works under MGNREGS should be implemented well planned and well ahead of time. Different programmes under MGNREGS should be implemented during lean period for the benefit of workers.

Frequent awareness programmes should be organized in a meaningful way through public awareness campaigns, conferences, village meetings and distribution of leaflets in educational institutions extensively in order to educate and sensitise the common people about the different aspects of implementation of MGNREGS.

The administration of different levels and of different bodies should have the commitment and sincerity in implementation of the scheme.

In fact, the Government's effort alone will not be able to implement any national programme like MGNREGS. Peoples' active and full participation is a must for the success of the scheme. For this purpose, special attention must be given by the Government to increase peoples' participation in the scheme.

In order to fulfil the objectives of the scheme, intensive efforts and attention is to be needed. There is an urgent need for a good governance, dedicated bureaucracy, strong political will, co-operation from all sections of the society, voluntary organizations i.e. Non-Governmental Organizations (NGOs) and Self Help Groups (SHGs) for successful implementation of the scheme.

\section{Emerging Facts:}

The empirical information obtained from the field by analyzing the different indicators, the study draws the following important observations:

- The performance of MGNREGS in generation of 100 days of guaranteed wage employment to rural household was not satisfactory.

- The scheme failed to provide the targeted 100 days of employment to the rural household in a financial year.

- The empirical data derived from the field revealed that one hundred days of wage employment round the year was not sufficient for rural unemployed. 96.50 per cent of the respondents asserted that the present target of 100 days of employment to the rural poor should be increased to minimum 150 days.

The MGNREGS has no positive impact on rural migration. 
- The scheme has failed to stop rural migration in Bankura district of West Bengal.

- Many young people migrated from rural to nearby urban areas in search of job or employment after implementation of MGNREGS.

- There was no record of any family or village members migrated back to village for work under MGNREGS.

- The results show that the main reason for failure of MGNREGS in reducing rural migration is the meagre wage rate under the scheme. The wage rate under MGNREGS is sizeably lower than the existing market rate. As a result, the rural unemployed were not interested ( 90.50 per cent) to work under MGNREGS.

- 100 per cent respondents asserted that the wage rate in cities or town was higher in comparison to MGNREGS. So, they were not satisfied with the wage rate under MGNREGS.

It can rightly be concluded that the MGNREGS failed in fulfilling its objectives. The study reveals that the incidence of labour migration took place in the study areas after (59 per cent) the implementation of MGNREGS. Thus, rural migration remains a living phenomenon in the villages under study.

The scheme's outcome in respect of timely payment of wages to the MGNREGS workers was not encouraging. The study reveals that the wages were not paid to workers in time.

No compensation was paid to worker for delayed payment of wages. The implementing authorities could not implement the scheme in accordance with the provisions of the Act. Some irregularities and gross violations of the MGNREGA - 2005 had taken place in implementation of the scheme.

The study very clearly indicates that MGNREGS failed to provide job or employment adequately to the rural poor.

Search of job or employment was the major determining factor of rural migration in selected villages under study.

Thus, at the end, it may be summed up that the above discussion and analysis shows it beyond any shadow of doubt that the implementation of MGNREGS does not make any remarkable success in reducing rural migration in Sarenga Development Block of Bankura District of West Bengal. The scheme could not ensure the targeted 100 days of guaranteed wage employment to every rural household in a financial year and has failed to bring any perceivable transformative outcomes in the issue of rural migration. In fact, the scheme was not successful in fulfilling its basic objectives. The study indicates that some irregularities and violations of the important provisions of the Act had taken place in implementation of the scheme. The implementing authorities could not implement the scheme in accordance with the letter and spirit of MGNREGA.

The study has brought to light the fact that the implementation of MGNREGS has been facing some significant loopholes. If all the loopholes could be brought under strict control, there will be no doubt that MGNREGS would be a boon against rural migration. Therefore, to make the programme more successful, intensive efforts and certain changes are still required in government plans and programme so as to fulfill its basic objectives.

Further, the literature survey suggests that the literature available on the present work is limited in number. In fact, the introduction of MGNREGS is a recent phenomenon. It may be logical to state that the scheme is still in experimental stage. No systematic major studies have so far been done in depth and detail on MGNREGS in the context of West Bengal. Therefore, specific research is needed on this issue in order to evaluate the impact of the scheme in reducing rural migration. This micro-study has brought some significant research questions that need to be verified on the basis of empirical data. It would not be 
wrong to say that the study will provide a base for further extensive research work in the field in future. Therefore, it will be a worthwhile effort if some scholars, academicians or researchers were to study on the fore issues in several districts of West Bengal or neighbouring states of West Bengal and compare the same with the other parts of the country to fully understand the impact of MGNREGS on rural migration.

\section{Acknowledgments:}

The Author is deeply indebted to the respondents for their kind co-operation and responding the questions free and frankly by spending their valuable time. The staffs of the Office of the Block Development Officers, Sarenga Development Block, District Nodal Officer, and MGNREGA of Bankura are equally claimants of author's sincere gratitude for providing necessary information during the course of study.

\section{References:}

1. Kuldip, S. Chhikara and Anand, S. Kodan (October 2012). Migration of Rural Women in India: Trends, Streams and Motivation. Greener Journal of Social Sciences, 2(4): 127-133.

2. http://www.iom.int/jahia/webdav/site/myjahiasite/shared/ shared/mainsite/published_docs/serial_publications/Gloss ary_eng.pdf.

3. Kuldip, S. Chhikara and Anand, S. Kodan, (October 2012). Op. cit.

4. Lee, E.S. (1970). A Theory of Migration. In G.J. Demko; H.M. Ross and G.A. Schnell, (Eds). An Introduction to Population (p - 290). New Delhi: Archives Books.

5. Sinha, B.R.K. (2005). Human migration: concept and approaches. Foldrajzi Ertesito, LIV(3-4): $403-414$.

6. International Migration, Health and Human Rights: 2013. World Health Organization \& High Commissioner of United Nations Human Rights. International Organization for Migration 17 route des Morillons, 1211 Geneva 19, Switzerland: 12-13.

7. www.nationalgeographic.com/xpeditions.

8. Sharma, Reetu (October 2012). Problems and Prospects of Small Scale Industrial Units (A Case Study of Exporting and Non - exporting Units in Haryana). Asia Pacific Journal of Marketing \& Management Review, 1(2): 191 - 210.

9. Sharma, Arpita (September 2014). Mgnrega - An Alternative to Migration. Kurukshetra, 62(11): 26-28.

10. Rossi, Andrea (March 2008). The Impact of Migration on Children in Developing Countries. A paper prepared for the Youth Migration Conference April 24-26, 2008 Bellagio, Italy.

11. Khan, Jabir Hasan; Hassan, Tarique and Shamshal (July - Dec 2011). Socio-Economic Causes of Rural to Urban Migration in India. Asia-Pacific Journal of Social Sciences, III(2): 138-158.

12. Das, Anuj Kumar (March 2013). Migration and its Socio-Economic Consequences in West Bengal. International Journal of Research in Economics \& Social Sciences, 3(2): 105 - 111.

13. Vinayakam, K. and Sekar, S.P. (Jan. - Feb. 2013). Rural To Urban Migration in an Indian Metropolis: Case Study Chennai City. IOSR Journal Of Humanities And Social Science, 6(3): 3235 .

14. Kumar, Parveen (September 2014). Kurukshetra, 62(11): 7- 10.

15. Mohapatra, Amiya Kumar (September 2014). Rural - Urban Migration in India-A Critical Review. Kurukshetra, 62(11): 18- 21.

16. Kalkoti, Gopal (September 2014). Status of Rural Migration - Need for Development Initiatives. Kurukshetra, 62(11): 14-17.

17. Kuldip, S. Chhikara and Anand, S. Kodan, (October 2012). Op. cit. 